\title{
Le champ de rêves
}

\author{
Bemard W. Andrews
}

\section{Prélude}

Le champ de rêves is an example of proestry, which is a new scholastic art-from that integrates different literary conventions, such as verse, voice (e.g., quotations), narrative or commentary, to provide an audience with a multi-dimensional perspective. Prosetry provides a forum for a writer to develop ideational relationships among different forms of communication, and to convey a holistic understanding of phenomenon to a reader. It can be read silently by an individual, or with partners in the manner of chamber music with each person reading a different part. Alternately, it can be performed on stage for an audience solo or with partners. Further, there are different approaches to proestry. One may use commentary to inform the verse, ${ }^{1}$ voices from the field to illuminate the narrative and verse, ${ }^{2}$ or text to elaborate on the poetry and prose. ${ }^{3}$ In this article, the narrative conveys the personal experience of the writer on the Plains of Abraham, and the poetry captures the feelings of the experience. ${ }^{4}$

Proestry has it roots in the notion of alternating poetry and prose which originated in Ancient Rome and was called "manipian satire." The combining of different forms of communication within one art form re-appeared with the performance of the first opera, Jacopo Peri's D afne, in Florence in 1597. Opera evolved into oratorio and music drama, and on the lighter side, into comic opera and musical theatre. ${ }^{5}$ Two diverse means of communicating musical ideas - jazz improvisation and Western European musical notation were integrated to create the swing band of the 1930's and 1940's. Combining poetry, quotations and text appeared in the work of Marshall McLuhan, although pre-dominantly as an explanatory exercise rather than an artistic one. ${ }^{6}$ Patrick D iamond and Carol Mullen went further and experimented with a form they refer to as "palimpsest" which involves using text to represent different voices and arranging them in a variety of ways, for example by alternating columns, juxtaposition, and writing in circles and spirals. ${ }^{7}$ Most recently, the

\footnotetext{
${ }^{1}$ For example, Bernard W. Andrews, "Strike up the Band!: Reflections on a Musical Life," Canadian Music Educator 42, Vol. 2 (2000): 22-24.

${ }^{2}$ For example, Bernard W. Andrews, "Land of Shadows," Language and Literacy 2, Vol. 1 http://eduss10educ.queensu.ca/ landl/

${ }^{3}$ For example, Bernard W. Andrews, "Man with the Golden Muse," The Recorder, 44, Vol. 1 (2001): 4243; "Prometheus Unbound," Canadian Music Educator, 42, Vol. 4 (2001): 42; and "Living a Learning," Manuscript submitted for publication.

${ }^{4}$ This approach was inspired by Laurel Richardson's writing, notably Fields of Play: Constructing an academic life (New Brunswick, NJ: Rutgers University Press, 1997).

${ }^{5}$ For a comprehensive account refer to David Ewen, Opera: Its Story Told Through the Lives and Works of Its Foremost Composers (New York, NY: Franklin Watts) and Alan J. Lerner, American Musical Theatre: A Celebration (New York, NY: McGraw-Hill, 1986).

${ }^{6}$ Refer to Marshall McLuhan, > From Cliché to Archetype (New York, NY: Viking Press, 1970).

${ }^{7}$ Refer to C.T. Patrick Diamond and Carol A. Mullen (Eds.), The Post-modern Educator: Arts-based Inquiries and Teacher Development (New York, NY: Peter Lang, 1999).
} 
advent of the electronic field has given rise to a range of new media, such as cell phones, television, fax, computers, digital recording and video graphics. The new media has blurred the distinction among art forms and created new ways for artists to communicate. For example, we now have soap operas, television plays, epic movies, music videos and telejournalism. Moreover, live performers, whether in the concert hall, nightclub or stadium, routinely rely on electronic media to considerable effect. ${ }^{8}$

\section{On the Plains of Abraham}

It is a late summer evening and I am standing on the Plains of Abraham. Behind me there are the usual city noises: people laughing, children crying, and the constant sound of traffic. Overhead, the crescent moon peeks through the clouds and eagerly seeks to draw the evening to a close. The night-lights challenge the stars' authority, but inevitably the darkness comes and there is quietness.

Tonight I feel terribly alone ...

Towards the edge of the plains there are the ageless trees and insurmountable cliffs that delineate the sea, the land, and the sky. In the faint distance, I can hear the distinct sounds of the Highland bagpipes. As the sounds grow nearer, they are accompanied by the recurring drumbeat of a relentless army of moving shapes. British troops guided by their Iroquois allies are crawling one by one up those insurmountable cliffs and entering into formation on the precipice. Gradually, a thin red line forms stretching endlessly across the Plains of Abraham. By the earliest morning hours, the Redcoats ${ }^{9}$ are resplendent in the wilderness against the moon-lit snow and azure-blue sky. It is September 13, 1759.

During the night, the French sentinels mistakenly assume that the British troops are reinforcements. Although overcome by the enemy, they are able to relay a message of the invasion to the Marquis de Montcalm. Immediately, the Marquis recalls his troops from Montmorency where they are engaged in a diversionary skirmish upriver with British warships. By early dawn, the French troops are also in formation. Alongside them, their Huron allies gleefully harass the thin red line.

Across the Plains of Abraham, two stone-faced generals, James Wolfe and Louis-Joseph de Montcalm, eye each other with quiet determination. This is not a battle for nationhood, rather it is an integral part of an ongoing conflict between two European superpowers. It is a war fought by continental troops in a conflict which stretches from Europe to India, and across the northern hemisphere. New France, like all colonial outposts, is but another pawn in a vicious power game played out in European capitals.

\footnotetext{
${ }^{8}$ Refer to Brad Hill, Going Digital: A Musician's Guide to Technology (New York, NY: Schirmer, 1998).

${ }^{9}$ The term "Redcoats" is a historical term referring to the British army of the eighteenth and nineteenth centuries who wore red tunics to amplify their presence on the field of battle. Folklore suggests that Paul Revere used the phrase "The Redcoats are coming! The Redcoats are coming!" as a rallying cry on his midnight ride from Concord to Lexington during the American Revolutionary War of Independence.
} 
The history books tell the story of the French attack, and how they advanced 100 yards, then 75 yards, then 50 yards, discharging their muskets into the thin red line. At 40 yards, their ammunition was nearly spent, and the British troops fired their first volley, a second volley, and once more again. And then, only the thin red line remained. Within thirty minutes the battle was over, and the two generals lay mortally wounded. In the Treaty of Paris of 1763, New France was retained by G reat Britain and abandoned by France. That year, the French troops were repatriated to Europe.

But on this field of dreams, there is another story. As the morning sun disintegrates into the swirling mists of time, the thin red line begins to fade. No one is killed or injured in the skirmish, and the British troops withdraw to their warships before another bitter winter sets in. It is the sovereignist dream.

But France still loses the Seven Years War and experiences a financial crisis. The monarchy decrees that New France, which includes most of Ontario, the Mississippi Valley and Louisiana, must become self-sufficient. Without substantial support from France or an unlikely partnership with the remaining well-fortified loyalist Maritime colonies, the Frenchspeaking communities are isolated and highly vulnerable to American revolutionary fervour. Indeed, the Americans envision a fourteenth state on their northern frontier giving them control of the St. Lawrence, the G reat Lakes and the Mississippi watershed. And in 1775 the Americans invade Q uébec City, a foreign power intent imposing its own destiny.

Before this revisionist future completely unfolds, however, the city noises - of people laughing, children crying, and the sound of morning traffic - break through the fading mist. I am no longer alone, and I am left now with my own thoughts.

What matters to me is that in 1775 when the Americans did invade Q uébec, they were not successful: they were defeated by French-Canadian militia and British troops. Again in the War of 1812, the fierce determination and allied efforts of English and French colonists, First Nations warriors, and British troops prevented the Stars and Stripes from rising over Upper and Lower Canada, and the Maritime colonies.

In 1871, British military units left Canada forever - one hundred and eight years after the French troops were repatriated to France. The British left behind a fledgling country, one which Q uébec joined at its inception in 1867 as a proud and voluntary partner. Indeed, in service to their country Canada, French-Canadians have distinguished themselves during the Great War in those terrible battles of Ypres, the Somme, Vimy Ridge, Passchendaele, and the final breakthrough of the Hindenburg Line. In the cause of freedom, they were central to the allied efforts that defeated the Nazis regime during World War II: at Catenanuova and Scalpello in Sicily; and again at Gambatesa, San Martino, San Fortunato and Casa Berardi in Italy. And most importantly, French-Canadians participated in the Northern European campaign of 1945 which freed Holland, Belgium and France from the German tyranny.

Given our history, is it not an ironic twist of fate that one hundred and eighty-six years after the Battle of the Plains of Abraham, France was liberated by Canadian, British and American troops? ... But what of this for Québec? 
I believe that we cannot know Québec until we stand on the Plains of Abraham and watch the thin red line disappear into the mists of time. The place is integral to the psyche of the Q uébecois and to their aspirations. I am told that the Battle of the Plains of Abraham occurs whenever the crescent moon is in the midnight sky. One must watch intently and listen carefully for Québec's heartbeat to truly see and understand.

\section{Rêvenie}

Ce soir la lune est claire

Dans le quatrième quartier

? travers le champ de rêves

J'entends les sons de la cornemuse

Je vois les objets de la guerre

Les Anglais ont passé

Par-dessus les falaises

Et ils s'alignent ? travers

Les plaines d'Abraham

Pour conquérir Québec

Les soldats de la France

Attaquent la mince ligne rouge

Il n'y a pas de feu

Encore ? soixante verges

Il n'y a pas de feu

Les soldats de la France

Continuent leur attaque

Fortement ils crient et hurlent

? cinquante verges encore

Il n'y a pas de feu

Et puis le temps venait

0 ? la mince ligne rouge doit

Fusiller les soldats

De la France mais le temps

S'arr? te ? quarante verges

Les soldats d'Angleterre

Commencent ? s'affaiblir

Dans la brume du matin

? trente verges de ces plaines

Il n'y a rien ? voir

C'est l'espoir du Q uébec

$Q$ ue la mince ligne rouge 
Disparaisse pour toujours

Et les aspirations

D es gens se réalisent

Ce soir la lune est claire

D ans le quarti? me quartier

Il faut compter que la

Mince ligne rouge s'affaiblisse

D ans les brouillards du temps

Pour toujours

\section{Bibliography}

Andrews, Bernard W. "Land of Shadows." L anguage and L iteracy 2, Vol. 1 http:// eduss10educ.queensu.ca/ landl//

Andrews, Bernard W. "Living a Learning." Manuscript submitted for publication.

Andrews, Bernard W. "Man with the Golden Muse," The Recorder, 44, Vol. 1 (2001): 42-43.

Andrews, Bernard W. "Prometheus Unbound." Canadian M usic E ducator, 42, Vol. 4 (2001): 42 .

Andrews, Bernard W. "Strike up the Band!: Reflections on a Musical Life." Canadian Music E ducator 42, Vol. 2 (2000): 22-24.

Diamond, C.T. Patrick, \& Mullen, Carol A. (Eds.). ThePost-modern E ducator: A rts-based Inquiries and Teacher D evelopment. Counterpoints: Studies in the post-modern theory of education, Vol. 89. New York, NY: Peter Lang, 1999.

Ewen, David 0 pera: Its Story T old Through the L ives and W ork s of Its F oremost C omposers. Mainstreams of music series, Vol. 1. New Y ork, NY: Franklin Watts, 1972.

Fetherling, D ouglas (Ed.). Canadian A neodotes. Peterborough, ON: Broadview Press, 1988.

Hall, Brad. G oing D igital: A M usician's G uide to Technology. New York, NY : Schirmer, 1998.

Leacock, Stephen. Canada: The F oundations of Its F uture. Montreal, PQ : House of Seagram, 1941.

Lerner, Alan J. The musical theatre: A celebration. New York, NY: McG raw-Hill, 1986. 
Martin, Lawrence. The A ntagonist: L ucien Bouchard and the Politics of D elusion. Toronto, ON: Penguin, 1997.

McLuhan, Marshall. From Cliché to A rchetype. New York, NY: Viking Press, 1970.

Morton, Desmond. A Military H istory of Canada. Edmonton, AB: Hurtig, 1985.

Palmer, Roy. The Sound of H istory: Songs and Social Comment. London, UK: Pimilico, 1988.

Richardson, Laurel. Fields of Play: C onstructing an A cademic L ife. New Brunswick, NJ: Rutgers University Press.

Stanley, George. Canada Invaded 1775-1776. Canadian War Museum Historical Publications, No. 8. Ottawa, O N: Canadian War Museum, 1977.

Swan, Conrad. Canada: Symbols of Sovereignty. Toronto, O N: University of Toronto Press, 1977.

Turner, Wesley. The W ar of 1812: The W ar Both Sides W on. O xford, UK: D undern Press, 1990. 